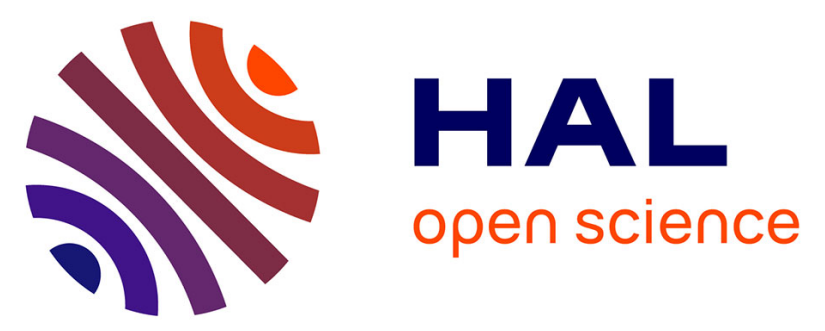

\title{
Assessment of mutualism between Bombus terrestris and its microbiota by use of microcolonies
}

Ivan Meeus, Veerle Mommaerts, Annelies Billiet, Hadi Mosallanejad, Tom

Wiele, Felix Wäckers, Guy Smagghe

\section{- To cite this version:}

Ivan Meeus, Veerle Mommaerts, Annelies Billiet, Hadi Mosallanejad, Tom Wiele, et al.. Assessment of mutualism between Bombus terrestris and its microbiota by use of microcolonies. Apidologie, 2013, 44 (6), pp.708-719. 10.1007/s13592-013-0222-9 . hal-01201343

\section{HAL Id: hal-01201343 \\ https://hal.science/hal-01201343}

Submitted on 17 Sep 2015

HAL is a multi-disciplinary open access archive for the deposit and dissemination of scientific research documents, whether they are published or not. The documents may come from teaching and research institutions in France or abroad, or from public or private research centers.
L'archive ouverte pluridisciplinaire HAL, est destinée au dépôt et à la diffusion de documents scientifiques de niveau recherche, publiés ou non, émanant des établissements d'enseignement et de recherche français ou étrangers, des laboratoires publics ou privés. 


\title{
Assessment of mutualism between Bombus terrestris and its microbiota by use of microcolonies
}

\author{
Ivan Meeus ${ }^{1}$, Veerle Mommaerts ${ }^{1}$, Annelies Billiet ${ }^{1}$, Hadi Mosallanejad ${ }^{1}$, \\ Tom Van de Wiele ${ }^{2}$, Felix Wäckers ${ }^{3}$, Guy SMAgGhe ${ }^{1}$ \\ ${ }^{1}$ Department of Crop Protection, Faculty of Bioscience Engineering, Ghent University, Coupure Links 653, 9000 \\ Ghent, Belgium \\ ${ }^{2}$ Laboratory of Microbial Ecology and Technology, Faculty of Bioscience Engineering, Ghent University, Ghent, \\ Belgium \\ ${ }^{3}$ Biobest NV, Westerlo, Belgium
}

Received 6 February 2013 - Revised 12 June 2013 - Accepted 28 June 2013

\begin{abstract}
Social pollinators, like honeybees and bumblebees, have specific microbiota. The specific association between the insect and its gut microbiota could lead to a functional dependence. In this project, we investigated whether an alteration in microbiota could influence the fitness of the generalist pollinator Bombus terrestris. We used bumblebee workers in microcolonies to assess effects on colony development and reproduction. Treatment with $200 \mathrm{ppm}$ streptomycin and tetracycline resulted in a disruption of gut microbiota, and typically there was $100 \%$ worker mortality. In contrast, treatment with streptomycin alone showed an improved reproduction and this concurred with a different gut microbiota pattern. The results are discussed in relation to effects of the gut microbiota on bumblebee fitness and potential beneficial effects by Lactobacillus sp. These data may open new avenues in the mass-rearing of bumblebees used for the biological pollination in agriculture.
\end{abstract}

host-microbe interactions / social pollinators / Bombus terrestris / streptomycin / Lactobacillus / probiotica

\section{INTRODUCTION}

Insects are arguably the most successful group of animals on the planet, occupying a diverse range of ecological niches. This ecological success is often facilitated by bacterial symbionts (Brownlie and Johnson, 2009). These acquired microbial genomes, among others, can synthesize required nutrients and cofactors for the insect host, enable the host to utilize

Electronic supplementary material The online version of this article (doi:10.1007/s13592-013-0222-9) contains supplementary material, which is available to authorized users.

Corresponding author: I. Meeus, ivan.meeus@ugent.be

Manuscript editor: James Nieh unusual or low-nutrient diets, give protection against parasitism and/or influence patterns of host plant use (Dillon et al., 2005; Moran et al., 2008; Riegler and O'Neill, 2007). Within the Apidae, a family of bees with an important ecological value in maintaining plant diversity and providing pollination services (Ghazoul, 2005; Steffan-Dewenter et al., 2005), especially honeybees and bumblebees are wellstudied. This is due to their economic value for the cultivation of pollinator-dependent crops (Aizen et al., 2008; Velthuis and van Doorn, 2006). The role of beneficial host-microbe interactions of social insects is currently under investigation. The honeybee and bumblebee gut microbiota has recently been identified, revealing a highly specific, yet overlapping community composition with low species diversity (Koch and Schmid-Hempel, 
2011a; Martinson et al., 2011; Koch et al., 2013). In other insects, the microbiota may be more variable within a single species. Indeed, the gut microbiota of common fruit flies from different locations showed variable species richness (Corby-Harris et al., 2007; Chandler et al., 2011), and diet plays a major role in shaping the gut microbiota of larvae of the gypsy moth (Broderick et al., 2004). The specific relation between the gut microbiota and social pollinators creates the opportunity to evolve a functional dependence. Progress has been made in elucidating the functionality of this specific microbiota in social pollinators. A metagenomic analysis revealed genes involved in biofilm formation and pectin-degrading enzymes (Engel et al., 2012). The gut microbiota is also involved in immunity; good examples are the protection against the gut parasite Crithidia bombi in bumblebees (Koch and Schmid-Hempel, 2011b) and American Foulbrood in honeybees (Forsgren et al., 2010). In summary, beneficial interactions between bacteria and social pollinators are to be expected.

In this project, we investigated this essential host-microbe interaction to see whether alterations of the microbiota in the gut of bumblebee workers can influence their fitness. We used Bombus terrestris, a eusocial generalist pollinator with an annual life cycle which is one of the most numerous bumblebee species in Europe and also commercially mass-reared for biological pollination in greenhouses particularly in tomatoes (Velthuis and van Doorn, 2006). This species offers the unique opportunity to use microcolonies, a standardized setup to study colony development and reproduction following exposure to different treatments (Mommaerts et al., 2006). Although microcolonies have already been used before in insecticide testing, we applied them for the first time to test whether the microbiota patterns in the gut of these workers are representative for a queen-right colony. With these microcolonies, we then determined whether antibiotic treatments like streptomycin and tetracycline can induce changes in the microbiota of bumblebees compared to untreated microcolonies. Subsequently, we scored the fitness of these microcolonies to evaluate whether changes in microbiota affect colony development and reproduction in order to identify certain beneficial bacterial species.

\section{MATERIALS AND METHODS}

\subsection{Insects}

All bumblebees were obtained from a continuous mass rearing program (Biobest, Westerlo, Belgium) and fed on commercial sugar water, containing methyl and propyl hydroxybenzoate at $0.6 \%$ (BIOGLUC ${ }^{\circledR}$, Biobest) and honeybee-collected pollen (Soc. Coop. Apihurdes, Pinofranqueado-C'aceres, Spain) as energy and protein source, respectively. The insects were kept under standardized laboratory conditions with $28-30{ }^{\circ} \mathrm{C}$, $60-65 \%$ relative humidity, and continuous darkness (Mommaerts et al., 2006).

\subsection{Microcolonies and measuring fitness of microcolonies}

We used microcolonies to quantify fitness effects of different antibiotic treatments on bumblebees. These microcolonies are created by placing newborn workers (exact numbers of bumblebees are given in each specific experiment) in an artificial nest box $(15 \times 15 \times 10 \mathrm{~cm})$. After 1 week one worker becomes dominant and starts laying unfertilized eggs that develop into drones while the other workers take care of the brood and forage for food. These microcolonies follow a well-defined development pattern with quantifiable parameters (i.e., time point of egg laying, larval development time, pupation time, reproductive output, and larval mortality). Microcolonies contain unfertilized workers that only produce male offspring. Hence the reproduction output can be determined by counting the numbers of drones and by weighing (Adventurer Pro AV413C) their mass. The microcolonies were kept at the standardized rearing conditions as reported above for the rearing.

Normal distribution of data was confirmed by Kolmogorov-Smirnov test $(P=0.05)$ and the mean \pm SD were analyzed by an independent-sample $t$ test $(P=0.05)$.

\subsection{Microbiota of workers in microcolonies compared to queen-right colonies}

Seven newborn workers were selected from one queen-right colony and placed in one microcolony box. This setup was performed for six queen-right colonies as biological replicates $(n=6)$. From each microcolony, we sampled one 4-day-old and one 8-day-old worker to 
determine the gut microbiota as described below. From the queen-right colony, the newborn workers were labeled and placed back in the colony. Then, three 0day-old, three 4-day-old, and three 8-day-old workers were sampled per colony and we characterized the gut microbiota as described below.

\subsection{Fitness and gut microbiota of workers in microcolonies treated with $200 \mathrm{ppm}$ streptomycin and tetracycline}

Each microcolony started with seven newborn workers coming from one queen-right colony. Per queen-right colony $(n=10)$, we started a control group (C; $n=10)$, and a continuous antibiotic treatment with streptomycin and tetracycline $(\mathrm{S}+\mathrm{T} ; n=10)$. The two antibiotics streptomycin and tetracycline were added at $200 \mathrm{ppm}$ in the diet, via treated sugar water and treated pollen as described in Mommaerts et al. (2006).

Fitness parameters of each microcolony were recorded as described above. For six microcolonies per treatment two bumblebees were sampled (at days 4 and 8 ) to determine the microbiota.

\subsection{Food uptake by workers after 200 ppm streptomycin and tetracycline treatment}

To investigate how the feeding of bumblebee workers with streptomycin- and tetracycline-treated diet (both at $200 \mathrm{ppm}$ ) affected the amount of food taken up by microcolonies, we followed food uptake in 20 microcolonies each originating from 10 randomly selected newborn workers. Firstly, all 20 received food ad libitum for 4 days. Then the experiment started (day 0), ten microcolonies were provided with treated sugar water and pollen (treatment $\mathrm{S}+\mathrm{T}$, as described above). As a negative control ten microcolonies were fed untreated sugar water and pollen. The mass of the pollen and sugar water was determined by weighing them on a digital microbalance (Adventurer Pro AV413C) before administering and reweighing after 1 day (consumption on day 1) and after 3 days (consumption of days 1-3). Thereafter, fresh pollen and sugar water were provided (control versus treatment), again mass was determined before administering and 3 days later (consumption of days 4-6). Normal distribution of food consumption data was confirmed by Kolmogorov-Smirnov test $(P=0.05)$ and the means \pm SD were analyzed by an independent-sample $t$ test $(P=0.05)$.

\subsection{Fitness and gut microbiota of workers in microcolonies treated with $200 \mathrm{ppm}$ streptomycin}

Twenty microcolonies were started with six newborn workers that were randomly selected from different queen-right colonies. Two different treatment groups were created each consisting of ten microcolonies: control microcolonies (C) were fed normal untreated sugar, while in treated microcolonies the sugar water was supplemented with 200 ppm streptomycin (S). Fitness parameters of each microcolony were recorded as described above. To determine the gut microbiota we sampled one 8-day-old worker from each of the 20 microcolonies.

\subsection{Characterization of the gut microbiota}

\subsubsection{DNA extraction}

The mid and hindgut regions of the worker bumblebee were separated from the crop and stored individually in $200 \mu \mathrm{l}$ of acetone for later analysis. Stored samples were washed three times with sterile phosphate-buffered saline (PBS, $\mathrm{pH}$ 7.4). For this purpose the gut was opened by gentle crushing in a microtube using a Teflon pestle in $200 \mu \mathrm{L}$ of PBS and then spun down at $10,600 \times g$. The pellets were incubated at $37{ }^{\circ} \mathrm{C}$ for $2 \mathrm{~h}$ in a $170-\mu \mathrm{L}$ lysozyme solution $(100 \mathrm{mg} / \mathrm{ml})$ followed by treatment with $25 \mu$ of Proteinase K (Sigma-Aldrich) for $1 \mathrm{~h}$ at $56{ }^{\circ} \mathrm{C}$. In order not to preferentially extract gram negative bacteria, the samples were transferred to $300 \mu \mathrm{l}$ of lysis buffer from the EZNA ${ }^{\circledR}$ Insect DNA Kit (Omega Bio-Tek) supplemented with $0.3 \mathrm{~g}$ of zirconia beads (diameter $0.1 \mathrm{~mm}$; BioSpec Products) and further homogenized by bead beating in the Fastprep TM FP 120 (Thermo Scientific). Further extraction was performed according to manufacturer's instructions.

\subsubsection{Fingerprinting the microbial community}

We generated a 16S rDNA gene molecular fingerprint of the microbiota of the bumblebee gut in order to analyze its structure and diversity. The bacterial $16 \mathrm{~S}$ rDNA was amplified without co-amplification of predominant eukaroytic DNA by nested PCR with the 
primers Eub8F and 984R for external PCR and 338FGC and 518R for internal PCR (Bakke et al., 2011). The reaction mixture contained $2 \mathrm{mM} \mathrm{MgCl} 2,0.3 \mathrm{mM}$ dNTP, $0.3 \mu \mathrm{M}$ primers, recombinant Taq DNA polymerase (Invitrogen), and $5 \mu \mathrm{L}$ of DNA extract for the external PCR and $1 \mu \mathrm{L}(1 / 50$ diluted external PCR product) for the internal PCR. A total of $25 \mu \mathrm{l}$ of internal PCR reaction mix was placed in the Sensoquest Labcycler for $2 \mathrm{~min}$ at $94{ }^{\circ} \mathrm{C}$ followed by 21 amplification cycles $\left(30 \mathrm{~s}\right.$ at $94{ }^{\circ} \mathrm{C}, 30 \mathrm{~s}$ at $50{ }^{\circ} \mathrm{C}$, and $60 \mathrm{~s}$ at $72{ }^{\circ} \mathrm{C}$ ) and then by $3 \mathrm{~min}$ at $72{ }^{\circ} \mathrm{C}$. For the external PCR, the same procedure was followed, except the annealing temperature was $53{ }^{\circ} \mathrm{C}, 25$ amplification cycles were used and the final elongation was extended from 3 to 20 min to complete the polymerization.

The 16S rDNA gene molecular fingerprint was generated by denaturing gradient gel electrophoresis (DGGE). Ten microliters of the PCR products were separated on an $8 \%(w / v ; 40 \%$ acrylamide, $2 \%$ bisacrylamide) gel with a denaturing gradient of 45 to $60 \% ; 100 \%$ denaturation refers to $7 \mathrm{M}$ urea and $40 \%$ deionized formamide. Electrophoretic separation was performed on the INGENYphorU (Ingeny) for $16 \mathrm{~h}$ at $120 \mathrm{~V}$ in $1 \times$ TAE buffer $(20 \mathrm{mM}$ Tris, $10 \mathrm{mM}$ acetate, $0.5 \mathrm{mM}$ EDTA $\mathrm{pH} 7.4)$ at $60{ }^{\circ} \mathrm{C}$. The gels were stained using SYBR Green (1:10,000 dilution, FMC BioProducts) in $1 \times \mathrm{TAE}$ for $20 \mathrm{~min}$ and visualized by UV transillumination (Vilbert Lourmat).

\subsubsection{Diversity analysis}

Statistical comparison of the DGGE patterns was done with Bionumerics software (Applied Maths, Kortrijk, Belgium). Similarity matrices were based on the Pearson correlation coefficient using data from matched bands. Dendrograms were calculated using the clustering algorithm of Ward (Van de Wiele et al., 2004). Differences in similarity were calculated by analysis of similarities (ANOSIM) (Clarke and Green, 1988; Clarke, 1993) using Primer version 6.1.10 software. It calculates a global $\mathrm{R}$ statistic which lies between -1 and +1 , with high values indicating a large degree of discrimination among groups.

The structural diversity of the microbiota is characterized by the Shannon index of general diversity $H$ (Vervaeren et al., 2006). The equation for the Shannon index is: $H=-\sum\left(n_{i} / N\right) \log \left(n_{i} / N\right)$, where $n_{i}$ is the height of the peak and $N$ the sum of all peak heights of the densitometric curve (Vervaeren et al., 2006).

Microbiota diversity analysis was based on the method of Lorenz as described (Mertens et al., 2005; Wittebolle et al., 2009). In short, two parameters were derived from the bacterial fingerprint. Firstly, species richness $(R)$, which is the number of bands. Secondly, the community organization $(\mathrm{Co})$, for which a low number (for example $25 \%$ ) represents a community with high evenness or with no specific dominant species (Marzorati et al., 2008).

For all data, normal distribution was confirmed by Kolmogorov-Smirnov test $(P=0.05)$ and then the means \pm SD were analyzed by an independent-sample $t$ test $(P=0.05)$ or one-way ANOVA and separated by a post hoc Tukey-Kramer test $(\alpha=0.05)$ using SPSS v. 16.0 .

\subsubsection{Identification of bacteria}

Bacterial species were identified by cloning the external PCR fragment of one control bumblebee and one streptomycin-treated bumblebee from a microcolony into a pJET1.2/blunt vector with the CloneJET PCR Cloning Kit (Thermo Fisher Scientific) following manufacturer's instructions. Afterwards, plasmids were transformed in competent Escherichia coli XL-1 Blue Cells by heat shock and then plated out on a carbenicillincontaining LB agar plate. After $16 \mathrm{~h}$ incubation, only three and two colonies were formed, respectively. From each clone a plasmid was purified using the Plasmid mini prep kit (Omega Bio-Tek) and sent for sequencing to LGC Genomics (Berlin, Germany). The place of the bacterial plasmids on the DGGE profile was determined after nested PCR with external vector-specific primers and the internal primers as described above.

\section{RESULTS}

\subsection{Microbiota of workers in microcolonies compared to queen-right colonies}

The development of the microbiota was followed in untreated queen-right colonies $(n=6)$ and from each colony we sampled nine workers [three newborn workers (callow workers) and three 
workers of 4 and 8 days old, respectively]. Newborn workers showed hardly any microbiota in their gut with a species richness $R$ of $0.17 \pm 0.41$. By day 4 , the gut microbiota had developed and was significantly different from day $0(R, P<0.05$, ANOVA). Over the subsequent 4 days, the community richness $R=10.14 \pm 3.62 \quad(P=0.53)$, the Shannon index of general diversity $H=0.87 \pm 0.18$ $(P=0.43)$, and the community organization $C o=$ $35.89 \pm 4.77(P=0.73)$ remained stable (day 4 compared to day 8; ANOVA; Figure 1a). Calculating the same parameters, we could not detect any difference between bumblebees from microcolonies $(n=6)$ (days 4 and 8 ) and those from queen-right colonies $(n=6)$ at days 4 and 8 (ANOVA, $R: P=0.94 ; H: P=$ 0.80 ; and $C o: P=0.49$; Figure $1 \mathrm{a})$. However, looking at the similarity of the DGGE patterns of queen-right colonies $(74.8 \pm 12.8)$ and microcolonies $(77.5 \pm 14.0)$ a higher similarity was found opposed to the similarity between queen-right colonies and microcolonies (62.9 \pm 9.4 ; Figure 1b). ANOSIM, comparing each queen-right colony with its corresponding microcolony, revealed some separation $(R=0.33 \pm 0.26)$, but none were significantly different. However, some were close to the $P=0.05$ (i.e., $P=0.07 ; P=0.14 ; P=0.10 ; P=$ $0.33 ; P=0.70 ; P=0.21$ ). Although most bands found within microcolonies corresponded with those found in queen-right colonies, we speculate that the early separation of callow workers from the nest has a minor effect on the development of the microbiota.

\subsection{Fitness and gut microbiota of workers in microcolonies treated with 200 ppm streptomycin and tetracycline}

We assessed the effect of a continuous antibiotic treatment with streptomycin and tetracycline $(\mathrm{S}+\mathrm{T})$ on the microbial development compared to no exposure to antibiotics (C). The microbiota was assessed at days 4 and 8 of six of the ten microcolonies (per treatment). While the bumblebees of the untreated microcolonies developed a microbiota as described above, no bands were detected in the DGGE patterns of the treated bumblebees. This indicates that after 4 and 8 days of treatment no bacteria had developed.
In parallel to the gut microbiota analysis, the fitness of these microcolonies was measured. The mixture of antibiotics resulted in $100 \%$ worker mortality after 4 weeks. In contrast, no mortality was scored after 50 days in the untreated control groups (C).

\subsection{Food uptake by workers after 200 ppm streptomycin and tetracycline treatment}

As shown in Figure 2, the food uptake of microcolonies having been fed an antibioticcontaining diet for 1 day was not significantly different as compared to the control group (for sugar water: independent sample $t$ test, $P=0.23$; for pollen: independent sample $t$ test, $P=0.36$ ). This demonstrates that the antibiotic-treated food did not have a direct antifeedant effect during the first day of treatment.

During the experiment, the colonies treated with streptomycin and tetracycline showed a decrease in sugar water and pollen consumption when comparing the mean consumption from day 1 to day 3 and from day 4 to day 6 (independent sample $t$ test; $P<0.05$ for sugar water and $P<0.05$ for pollen; Figure 2). In contrast, the sugar water consumption in untreated colonies increased as the workers of the colony started to make sugar pots.

\subsection{Fitness and gut microbiota of workers in microcolonies treated with 200 ppm streptomycin}

We recorded a shift in the microbiota of bumblebees receiving $200 \mathrm{ppm}$ streptomycin (S; $n=10$; day 8 ) compared to control microcolonies $(\mathrm{C} ; n=10$; day 8$)$. First, the general diversity of the microbiota dropped sharply as illustrated in Figure $3 \mathrm{~b}$ by the Shannon index $H$ (independent $t$ test with unequal variance $P<0.001$ ) and species richness $R$ (independent $t$ test, $P<0.001$ ). Second, the bacterial identity was also different with control (C) bumblebees clustering separately from streptomycin-treated ones (S; Figure 3a). The bands highlighted in red (Figure $3 \mathrm{a}$ ) are unique to the streptomycin-treated colonies. Indeed their relative position in the DGGE gel is different from 


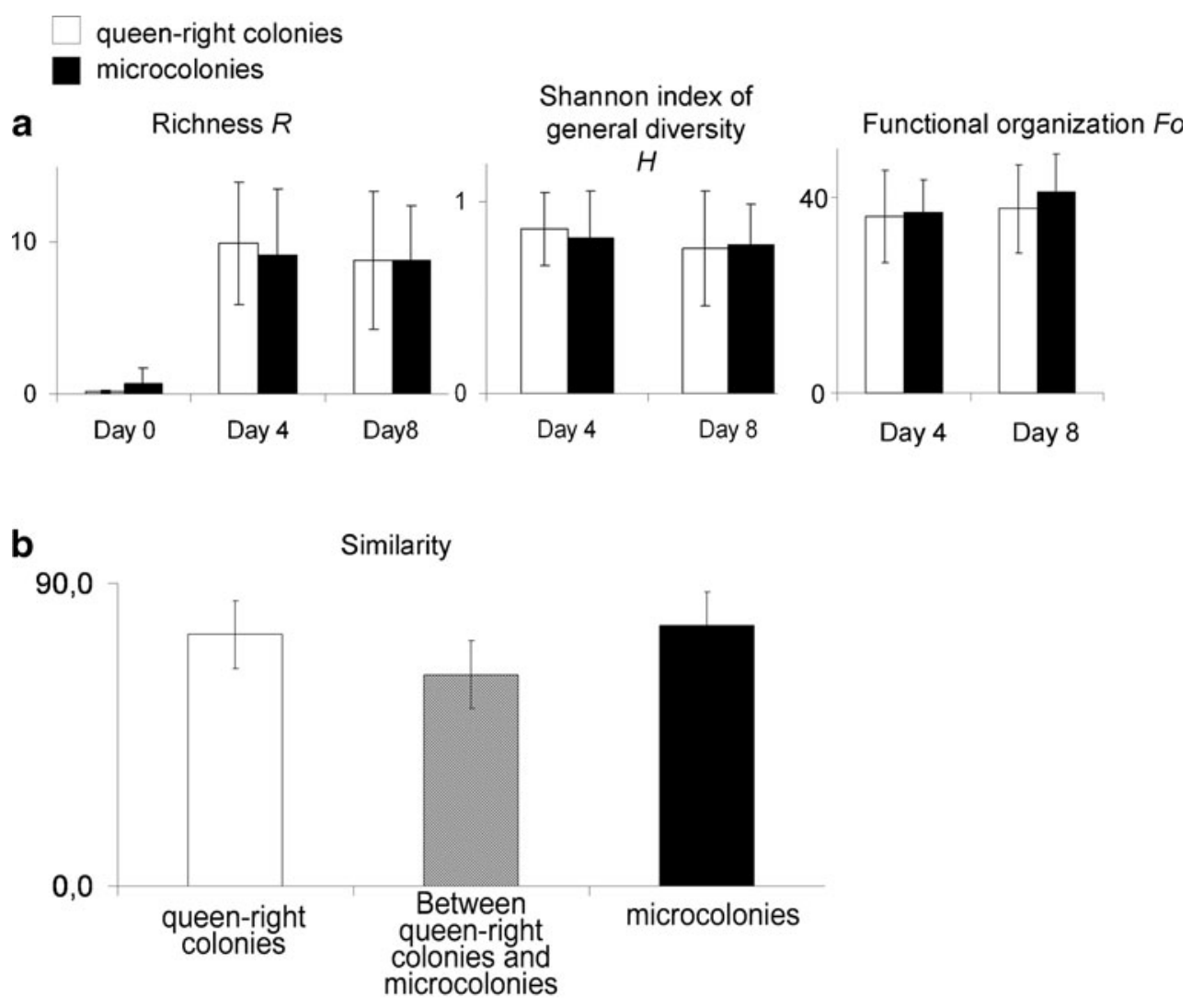

Figure 1. a The community richness $R$, the Shannon index of general diversity $H$, and the functional organization $F o$ of bumblebee workers from queen-right colonies versus microcolonies. b Similarity of queenright colonies and microcolonies and between queen-right colonies and microcolonies, based on the Pearson correlation coefficient using data from matched bands

the two closest bands present in the untreated control samples (see supplementary information Table S1). The red colon punctuations in Figure $3 \mathrm{a}$ also represent unique bands in the streptomycin treatments, but these have a very weak intensity that was only visible upon contrast and brightness adjustments.

The two red bands unique for the streptomycintreated samples were identified as the same bacterial species, namely Lactobacillus sp. (deposited at GenBank as KC477412) as had been previously isolated from the honeybee (GenBank HM534867). The bands mainly present in untreated bumblebees and here represented in blue are a Snodgrasella sp. (deposited at GenBank as KC477411) and a Bifidobacterium sp. (deposited at GenBank as
KC477410), both of which had previously been identified in wild bumblebees (Koch and SchmidHempel, 2011a,b).

When evaluating the fitness effects of the 200 ppm streptomycin treatment $(\mathrm{S} ; n=10)$, we observed no loss of survival of treated workers and also a normal development of the microcolony: the first egg was laid at $8 \pm 1$ days, the first pupa was formed at day $21 \pm 1$ and the first drone emerged at day $33 \pm 1$ (independent sample $t$ test; first egg: $P=$ 0.14 , first pupa: $P=0.50$, first drone $P=1.0$ ). However, the numbers of drones that emerged after 50 days were significantly increased by about $20 \%$ from $32.8 \pm 5.9$ in the untreated colonies to $39.2 \pm 4.3$ in streptomycin-treated colonies (S; independent sample $t$ test, $P<0.05$ ). Interestingly, 


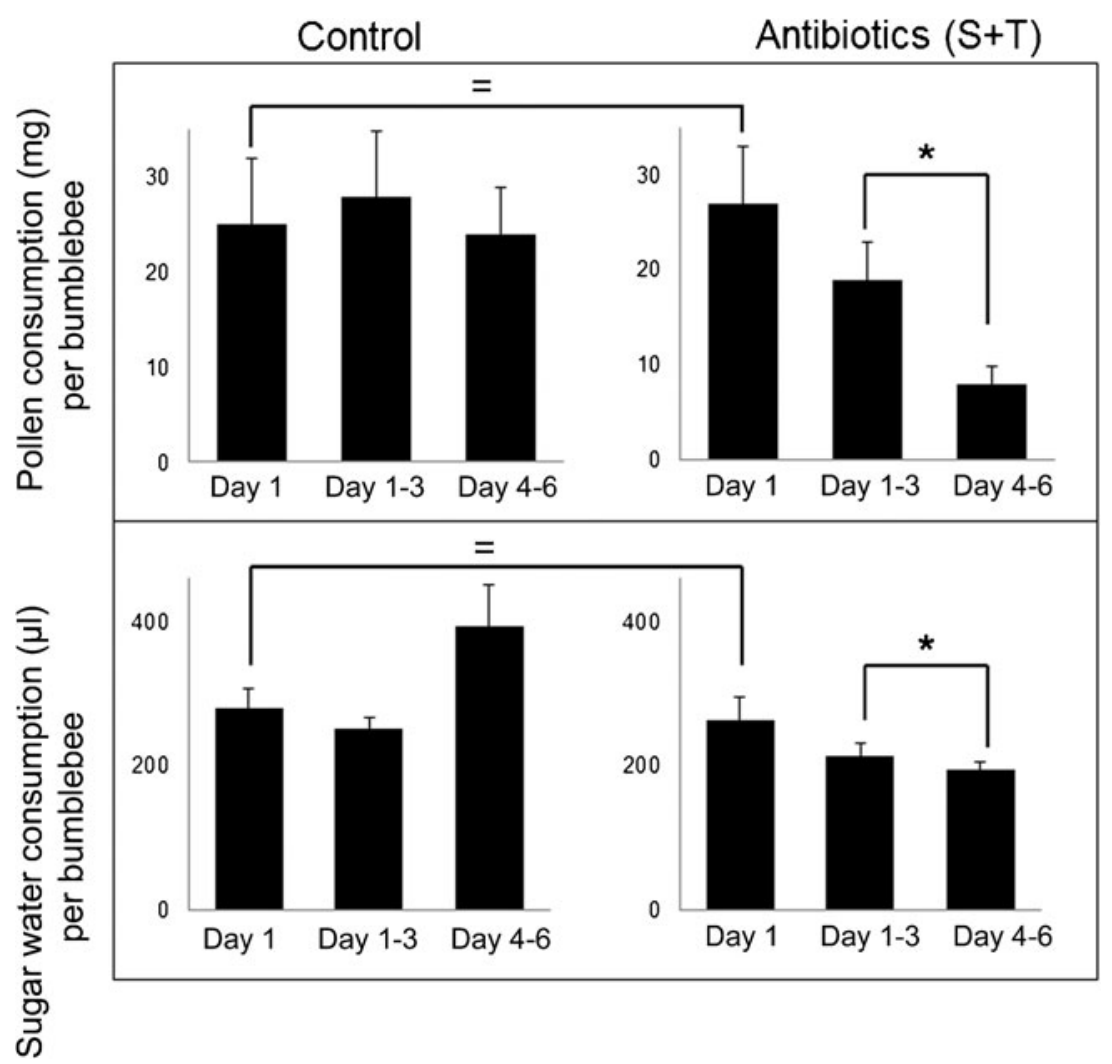

Figure 2. Mean individual sugar water $(\mu \mathrm{l})$ and pollen $(\mathrm{mg})$ consumption of ten bumblebees per colony ( \pm SD of ten colonies). Equal signs addition of streptomycin and tetracycline to sugar water and pollen does not reduce consumption at day $1(n=10)$. Asterisks a drop in consumption $(P<0.05)$ is recorded when comparing the average consumption in days 1,2 , and $3(n=10)$ with 4,5 , and $6(n=10)$

there was also an increase of more than $15 \%$ in the individual drone mass with $345 \pm 57 \mathrm{mg}$ in the streptomycin-treated colonies compared to $293 \pm$ $59 \mathrm{mg}$ in the untreated colonies (independent sample $t$ test, $P<0.05$; Figure 4).

\section{DISCUSSION}

In order to create an altered microbiota in microcolonies we used an antibiotic treatment. First we used a continuous treatment with two broad range antibiotics, namely streptomycin and tetracycline both at $200 \mathrm{ppm}$. This resulted in a total eradication of gut bacteria and a dramatic negative impact on bumblebee fitness, resulting in $100 \%$ mortality (at week 4) compared to no mortality in bumblebees with a microbiota. One reason that we observed mortality in bumblebee workers treated with these antibiotics could be that the bumblebees died due to starvation because the treated food may have posed an antifeedant effect. We measured no difference in food uptake between treated and control colonies in the first day after administering the antibiotics, which allows the conclusion that antibioticsupplemented food had no direct antifeedant effect on the bumblebees (Figure 2). But in continuation of the experiment, the bumblebees from the antibiotics-treated colonies showed a loss of appetite between days 1-4 and days 4-6 as expressed in a reduced uptake of both pollen and sugar water (Figure 2). Two possibilities remain to explain the loss of appetite followed by the death of the workers. The antibiotics had a direct toxic effect. Although similar dosage of antibiotics is regularly used to preserve food for insect mainte- 
a

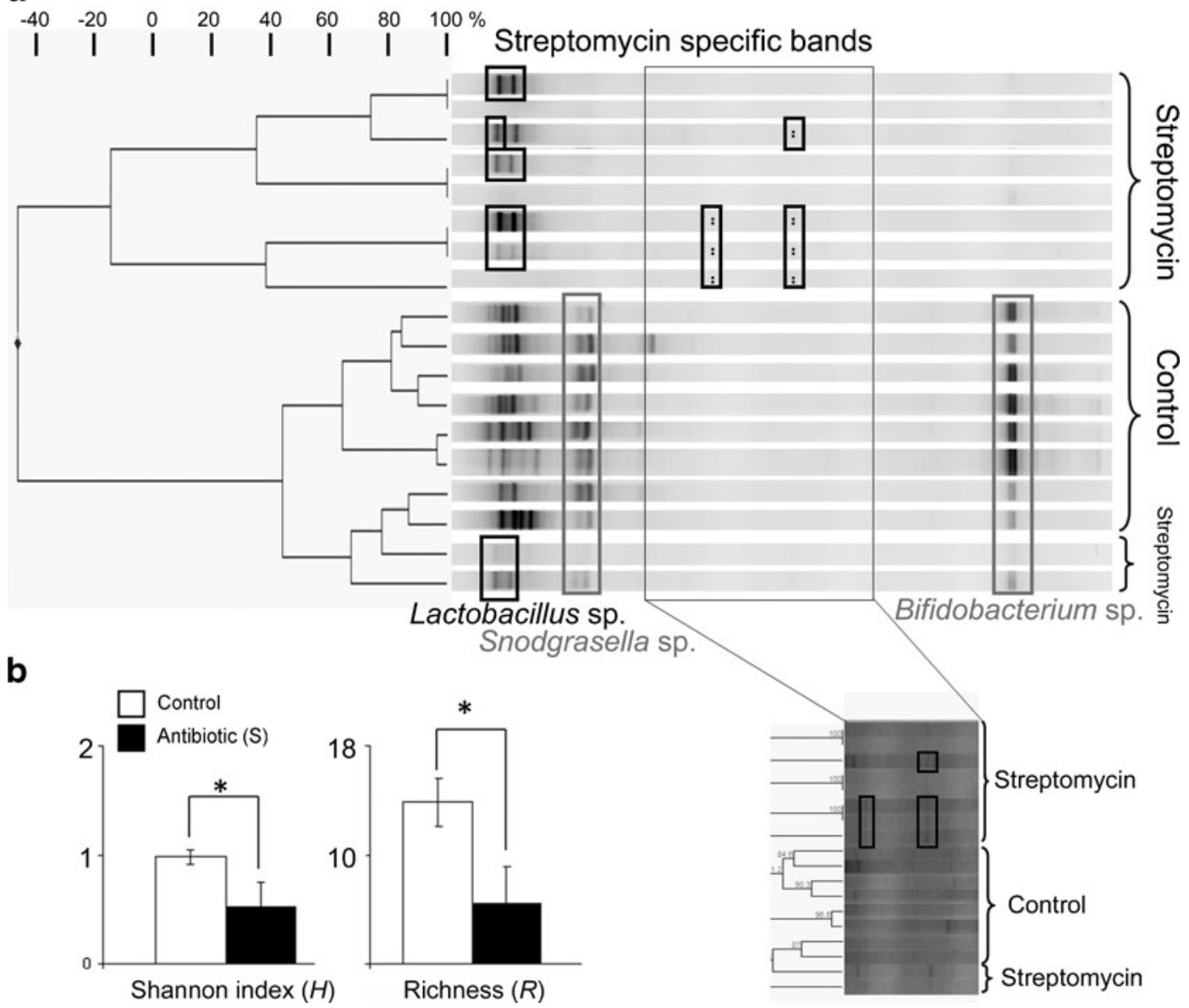

Figure 3. a The dendrogram shows that major bacterial species mainly disappear after streptomycin treatment. Bands highlighted in black are unique in streptomycin samples. Colon punctuations represent unique low-intensity DNA bands (cropped image below shows the presence of the low-intensity DNA bands after adjusting contrast and brightness). The grey box shows overlapping expression between two streptomycin-treated samples with the control. The bands in the grey boxes of streptomycin-treated samples show lower expression compared to the band representing Lactobacillus sp. (GenBank KC477412). b Significant drop in species mean richness $R \pm \mathrm{SD}(n=10 ; P<0.001)$ and the mean Shannon index $H \pm \mathrm{SD}(n=$ $10 ; P<0.001)$ after streptomycin treatment

nance under laboratory conditions or to cure insects from endosymbionts (Breeuwer and Werren, 1990; Wilkinson, 1998), it is also known that tetracycline can have host toxicity, mainly by inhibiting the mitochondrial protein synthesis (McKee et al., 2006). Therefore previous reports have assigned mortality of honeybee larvae receiving tetracycline (Peng et al., 1992) and adult bumblebees receiving antibiotic mixtures (Koch and Schmid-Hempel, 2011b) to direct toxic effects. However, the death of the treated workers could be due to an indirect toxic effect of the two antibiotics as the absence of a gut microbiota can cause a loss of appetite which in turn may lead to starvation. Two main mechanisms could underlie this. First, impaired pollen digestion could possibly result in gut obstruction and reduced nutrient uptake. Histochemical staining of embedded sections of the 

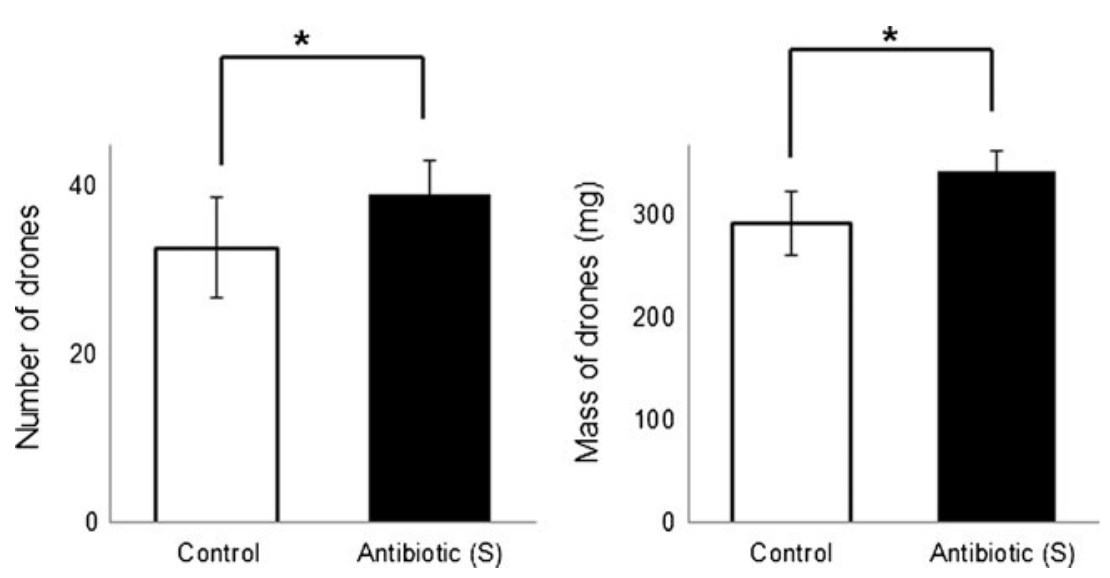

Figure 4. Increase in the mean drone production $\pm \mathrm{SD}(n=10 ; P<0.05)$ and mean mass of drones $\pm \mathrm{SD}(n=20$; $P<0.01)$ in streptomycin-treated colonies

alimentary canal of honeybees showed that pollen wall components like hemicelluloses and pectic acids undergo partial digestion (Klungness and Peng, 1984), suggesting that the bacterial community assists pollen digestion. Indeed the genomes of honeybee and bumblebee do not encode pectinase (Weinstock et al., 2006; The bumblebees Genome Sequencing Consortium, unpublished data), while for instance gammaproteobacteria do (Engel et al., 2012). Second, the antibiotics treatment may have impaired the nutrient synthesis by (endo)symbiontic bacteria in the insect which in turn may have resulted in bumblebee fatigue. It has already been suggested that bacterial metabolites like short chain fatty acids act as molecules with nutritional value for bees (Martinson et al., 2011).

In microcolonies treated with streptomycin alone we observed opposite effects compared to treatment with the two antibiotics $(\mathrm{S}+\mathrm{T})$ together, as these performed better than the controls (Figure 4). Streptomycin is bactericidal mainly for gram-negative bacteria but also for some gram-positive ones, and therefore a shift in the bacterial community was to be expected. Since the bumblebee gut microbiota has already been characterized (Koch and Schmid-Hempel, 2011a), we can speculate about the effects of treatment with streptomycin. The gram-negative bacteria (i.e., gammaproteobacteria, betaproteobacteria, and bacteriodetes) that are normally present in the bumblebee gut will have difficulties to grow, leaving a selective advantage for the gram-positive bacteria such as Firmicutes, Lactobacillus, and Bifidobacteria. Indeed, the microbiota in streptomycin-treated (S) bumblebees clusters separately from the untreated $(\mathrm{C})$ ones (Figure 3a). The DGGE pattern of streptomycin-treated bumblebees mainly consists of Lactobacillus sp. However, it should be remarked that the fact that the treatment with streptomycin alone resulted in unique bands, does not mean that the representative bacteria are not present in the control samples. Indeed some queen-right colonies also harbored this specific Lactobacillus sp. (data not shown). We believe that the streptomycin treatment here created an environment for the Lactobacillus sp. to further colonize the gut, perhaps by spilling over from biofilms in the insect crop since many Lactobacillus species tend to reside in these environments (Vasquez et al., 2012). In order to get more insights into the colonization dynamics of Lactobacillus in the bumblebee gut, quantitative PCR of Lactobacillus sp. is needed to determine changes in bacterial load. Furthermore by fluorescence in situ hybridization with Lactobacillusspecific 16S rRNA probes, one can visualize the microhabitat of the targeted bacteria (Moter and Göbel, 2000).

If we look at the natural occurrence of the identified Lactobacillus sp. we saw a $100 \%$ max 
identity with Lactobacillus sp. previously identified in honeybees. Based on Babendreier et al. (2007) and Martinson et al. (2011), this bacteria belongs to the Firm-5 phylotype, which is reported as a phylotype specific for corbiculate bees (Martinson et al., 2011). Our specific sequence, KC477412, actually has not been detected in bumblebees before (Koch and Schmid-Hempel, 2011a; Koch et al., 2013). The closest matches are bumblebee gut bacterial sequences AJ971929 (97 \% max identity) (Mohr and Tebbe, 2007), JQ388898, and JQ388899.1 (96\% max identity). On the contrary, in honeybees, the KC477412 is quite common (Martinson et al., 2011). We speculate that Lactobacillus sp. (KC477412) only occurs in low numbers in wild bumblebees and it got introduced in commercial bumblebees by their contact with honeybee collected pollen and further got established after streptomycin treatment.

When scoring the fitness of the microcolonies treated with streptomycin alone, it was interesting that these showed an improved fitness with higher drone numbers and higher drone masses. For humans, beneficial properties of lactic acid bacteria have been described as ingestion of lactic acid bacteria has been associated with a range of health benefits, including immune system modulation and increased resistance to malignancy and infectious illness (Soccol et al., 2010). In addition, Lactobacillus sp. is known to produce exopolysaccharides for biofilm formation to protect against invading "negative" bacteria (Vasquez et al., 2012). Vasquez et al. (2012) speculated that the potential health benefits of exopolysaccharides in humans could also apply for bees.

In conclusion, in this project we altered the gut microbiota of bumblebees (B. terrestris) by use of antibiotics, which in turn had effects on the fitness of these bumblebee workers. We mainly explain our results through beneficial effects by Lactobacillus sp. but the possibility also remains that the positive fitness effects are a consequence of the loss of "negative" bacteria. We used reared bumblebees, and although the three bacterial species identified were identical with those previously identified in wild bumblebees or honeybees, wild bumblebees probably have a different microbial community composition. Therefore our results cannot be extrapolated toward wild bumblebees. Further research on these aspects of microbiological communities in the insect gut and insect-microbe interactions may open new innovative avenues in the massrearing of bumblebees used for the biological pollination in agriculture.

\section{ACKNOWLEDGMENTS}

This study was supported by the Fund for Scientific Research Flanders (FWO-Vlaanderen) and the Institute for the Promotion of Innovation by Science and Technology in Flanders (IWT, Brussels, Belgium). H. Mosallanejad is now staff of Iranian Research Institute of Plant protection which is acknowledged.

Evaluation du mutualisme entre Bombus terrestris et son microbiote grâce à l'utilisation de micro-colonies

Interactions hôte-micro-organisme / pollinisateur / insecte social / Bombus terrestris / streptomycine / Lactobacillus / probiotique

Abschätzung des Mutualismus zwischen Bombus terrestris und seinen Mikrobioten durch Verwendung von Mikrokolonien

Wirt-Mikroben-Interaktionen / soziale Bestäuber / Bombus terrestris / Streptomycin / Lactobacillus / Probiota

\section{REFERENCES}

Aizen, M.A., Garibaldi, L.A., Cunningham, S.A., Klein, A.M. (2008) Long-term global trends in crop yield and production reveal no current pollination shortage but increasing pollinator dependency. Curr. Biol. 18(20), 1572-1575

Babendreier, D., Joller, D., Romeis, J., Bigler, F., Widmer, F. (2007) Bacterial community structures in honeybee intestines and their response to two insecticidal proteins. FEMS Microbiol. Ecol. 59(3), 600-610

Bakke, I., De Schryver, P., Boon, N., Vadstein, O. (2011) PCR-based community structure studies of bacteria associated with eukaryotic organisms: A simple PCR strategy to avoid co-amplification of eukaryotic DNA. J. Microbiol. Meth. 84(2), 349-351

Breeuwer, J.A., Werren, J.H. (1990) Microorganisms associated with chromosome destruction and repro- 
ductive isolation between two insect species. Nature 346(6284), 558-560

Broderick, N.A., Raffa, K.F., Goodman, R.M., Handelsman, J. (2004) Census of the bacterial community of the gypsy moth larval midgut by using culturing and culture-independent methods. Appl. Environ. Microbiol. 70(1), 293-300

Brownlie, J.C., Johnson, K.N. (2009) Symbiont-mediated protection in insect hosts. Trends Microbiol. 17(8), 348-354

Chandler, J. A., Lang, J. M., Bhatnagar, S., Eisen, J. A., Kopp, A. (2011) Bacterial communities of diverse Drosophila species: Ecological context of a hostmicrobe model system. PLoS Genetics 7(9) doi:10.1371/journal.pgen.1002272

Clarke, K.R. (1993) Nonparametric multivariate analyses of changes in community structure. Aust J Ecol 18(1), 117-143

Clarke, K.R., Green, R.H. (1988) Statistical design and analysis for a biological effects study. Mar. Ecol. Progr. 46(1-3), 213-226

Corby-Harris, V., Pontaroli, A.C., Shimkets, L.J., Bennetzen, J.L., Habel, K.E., Promislow, D.E.L. (2007) Geographical distribution and diversity of bacteria associated with natural populations of Drosophila melanogaster. Appl. Environ. Microbiol. 73(11), 3470-3479

Dillon, R.J., Vennard, C.T., Buckling, A., Charnley, A.K. (2005) Diversity of locust gut bacteria protects against pathogen invasion. Ecol. Lett. 8(12), 1291-1298

Engel, P., Martinson, V.G., Moran, N.A. (2012) Functional diversity within the simple gut microbiota of the honey bee. Proc. Natl. Acad. Sci. U S A 109(27), 1100211007

Forsgren, E., Olofsson, T.C., Vasquez, A., Fries, I. (2010) Novel lactic acid bacteria inhibiting Paenibacillus larvae in honey bee larvae. Apidologie 41(1), 99-108

Ghazoul, J. (2005) Buzziness as usual? Questioning the global pollination crisis. Trends Ecol. Evol. 20(7), 367-373

Klungness, L.M., Peng, Y.S. (1984) A histochemicalstudy of pollen digestion in the alimentary canal of honeybees (Apis mellifera L). J. Insect Physiol. 30(7), 511-521

Koch, H., Schmid-Hempel, P. (2011a) Bacterial communities in central European bumblebees: Low diversity and high specificity. Microb. Ecol. 62(1), 121-133

Koch, H., Schmid-Hempel, P. (2011b) Socially transmitted gut microbiota protect bumble bees against an intestinal parasite. Proc. Natl. Acad. Sci. U S A 108(48), 19288-19292

Koch, H., Abrol, D.P., Li, J., Schmid-Hempel, P. (2013) Diversity and evolutionary patterns of bacterial gut associates of corbiculate bees. Mol. Ecol. 22(7), 2028-2044

Martinson, V.G., Danforth, B.N., Minckley, R.L., Rueppell, O., Tingek, S., Moran, N.A. (2011) A simple and distinctive microbiota associated with honey bees and bumble bees. Mol. Ecol. 20(3), 619-628

Marzorati, M., Wittebolle, L., Boon, N., Daffonchio, D., Verstraete, W. (2008) How to get more out of molecular fingerprints: practical tools for microbial ecology. Environ. Microbiol. 10(6), 15711581

McKee, E.E., Ferguson, M., Bentley, A.T., Marks, T.A. (2006) Inhibition of mammalian mitochondrial protein synthesis by oxazolidinones. Antimicrob. Agents Chemother. 50(6), 2042-2049

Mertens, B., Boon, N., Verstraete, W. (2005) Stereospecific effect of hexachlorocyclohexane on activity and structure of soil methanotrophic communities. Environ. Microbiol. 7(5), 660-669

Mommaerts, V., Sterk, G., Smagghe, G. (2006) Hazards and uptake of chitin synthesis inhibitors in bumblebees Bombus terrestris. Pest. Manag. Sci. 62(8), 752-758

Moran, N.A., McCutcheon, J.P., Nakabachi, A. (2008) Genomics and evolution of heritable bacterial symbionts. Annu. Rev. Genet. 42, 165-190

Mohr, K.I., Tebbe, C.C. (2007) Field study results on the probability and risk of a horizontal gene transfer from transgenic herbicide-resistant oilseed rape pollen to gut bacteria of bees. Appl. Microbiol. Biotechnol. 75(3), 573-582

Moter, A., Göbel, U.B. (2000) Fluorescence in situ hybridization (FISH) for direct visualization of microorganisms. J. Microbiol. Meth. 41(2), 85-112

Peng, Y.S.C., Mussen, E., Fong, A., Montague, M.A., Tyler, T. (1992) Effects of chlortetracycline of honey-bee worker larvae reared in vitro. J Invert. Pathol. 60(2), 127-133

Riegler, M., O'Neill, S.L. (2007) Evolutionary dynamics of insect symbiont associations. Trends Ecol. Evol. 22(12), 625-627

Soccol, C.R., Vandenberghe, L.P.D., Spier, M.R., Medeiros, A.B.P., Yamaguishi, C.T., Lindner, J.D., Pandey, A., Thomaz-Soccol, V. (2010) The potential of probiotics: a review. Food. Tech. Biotechnol. 48(4), 413-434

Steffan-Dewenter, I., Potts, S.G., Packer, L. (2005) Pollinator diversity and crop pollination services are at risk. Trends Ecol. Evol. 20(12), 651-652

Van de Wiele, T., Boon, N., Possemiers, S., Jacobs, H., Verstraete, W. (2004) Prebiotic effects of chicory inulin in the simulator of the human intestinal microbial ecosystem. FEMS Microbiol. Ecol. 51(1), 143-153

Vasquez, A., Forsgren, E., Fries, I., Paxton, R.J., Flaberg, E., Szekely, L., Olofsson, T.C. (2012) Symbionts as major modulators of insect health: Lactic acid bacteria and honeybees. PLoS One 7(3), e33188. doi:10.1371/journal.pone.0033188

Velthuis, H.H.W., van Doorn, A. (2006) A century of advances in bumblebee domestication and the economic and environmental aspects of its commercialization for pollination. Apidologie 37(4), $421-451$ 
Vervaeren, H., Temmerman, R., Devos, L., Boon, N., Verstraete, W. (2006) Introduction of a boost of Legionella pneumophila into a stagnant-water model by heat treatment. FEMS Microbiol. Ecol. 58(3), 583-592

Weinstock, G.M., Robinson, G.E., Gibbs, R.A., Worley, K.C., Evans, J.D., et al. (2006) Insights into social insects from the genome of the honeybee Apis mellifera. Nature 443(7114), 931-949
Wilkinson, T.L. (1998) The elimination of intracellular microorganisms from insects: an analysis of antibiotic-treatment in the pea aphid (Acyrthosiphon pisum). Comp. Biochem. Physiol. Mol. Integr. Physiol. 119(4), 871-881

Wittebolle, L., Marzorati, M., Clement, L., Balloi, A., Daffonchio, D., Heylen, K., Vos, P.D., Verstraete, W., Boon, N. (2009) Initial community evenness favors functionality under selective stress. Nature 458, 623-626 